\title{
Maritime Communications Network Development Using Virtualised Network Slicing of 5G Network
}

\author{
Razvoj mreže pomorskih komunikacija korištenjem \\ raščlanjivanja virtualizirane $5 G$ mreže
}

\author{
Gajewski Sławomir \\ Gdansk University of Technology \\ Faculty of Electronics, Telecommunications \\ and Electronics, Poland \\ e-mail: slagaj@eti.pg.edu.pl
}

\begin{abstract}
Summary
The paper presents the review on perspectives of maritime systems development at the context of $5 \mathrm{G}$ systems implementation and their main properties. Firstly, 5G systems requirements and principles are discussed, which can be important for maritime applications. Secondly, the problems of network softwarisation, virtualisation and slicing, and possible types of services for potential implementation in $5 \mathrm{G}$ marine applications are described. Next, the proposed model for network slicing dedicated to maritime systems is discussed, and 5 G maritime systems architectures, including both terrestrial and satellite communications, are presented. The goal of the paper is to present the actual state of the art of 5G solutions for maritime applications as well as the analysis of network slicing and virtualisation for marine services implementation. The paper is based on original author contribution for network slicing models dedicated to marine applications which has not been previously published anywhere.
\end{abstract}

\section{Sažetak}

Ovaj članak predstavlja pregled perspektive razvoja pomorskih sustava u kontekstu implementacije 5G sustava i njegovih glavnih svojstava. Na prvome mjestu raspravlja se o zahtjevima $5 G$ sustava i principa, koji mogu biti važni za pomorske aplikacije. Na drugome mjestu govori se o problemu razvoja mrežnoga softvera: virtualizaciji i raščlanjivanju i mogućim tipovima usluga za potencijalnu implementaciju $5 G$ pomorskih aplikacija. Nadalje, predloženi model raščlanjivanja posvećen je pomorskima sustavima te se predstavlja $5 \mathrm{G}$ arhitektura pomorskih sustava, uključujući i terestičku i satelitsku komunikaciju. Cilj je ovoga rada predstaviti stvarno stanje stvari $5 G$ rješenja za pomorske aplikacije, kao i analizu raščlanjivanja mreže i virtualizaciju implementacije pomorskih rješenja. Članak se temelji na dosad neobjavljenome originalnom autorovu doprinosu u polju raščlanjivanja mrežnih modela.

\author{
DOI 10.17818/NM/2020/1.11 \\ UDK $621.396: 656.61$ \\ Review / Pregledni rad \\ Paper accepted / Rukopis primljen: 11. 9. 2019.
}

\section{KEY WORDS \\ $5 G$ \\ network slicing \\ virtualisation \\ maritime communication}

$5 \mathrm{G}$ architecture

\author{
KLJUČNE RIJEČI \\ $5 G$ \\ raslojavanje mreže \\ virtualizacija \\ pomorske komunikacije \\ $5 G$ arhitektura
}

\section{INTRODUCTION / Uvod}

The development of radio communication systems towards 5G, based on $3^{\text {rd }}$ Generation Partnership Project (3GPP) standard opens a new era in terms of the implementation and realisation of telecommunications services.[17] It is no secret that the technological solutions used in marine radio communication systems diverge significantly from the technological level of terrestrial cellular systems. At present, marine solutions are mainly focused on GMDSS (Global Maritime Distress and Safety System), which, to a significant extent, fulfil the basic needs in the field of sea safety. However, they do not meet the basic needs in terms of access to telecommunications services, including speech and broadband data transmission. It means that seamen and other sea workers have unbelievably limited access to services for today's realities.
Admittedly, in the case of seagoing vessels sailing in inland seas, these deficiencies are often complemented by the proximity of the sea coast and access to terrestrial cellular systems, but in many places, this access is sharply limited. There are also various satellite systems providing services, but their capabilities are also limited. It seems that nowadays, also in the context of the anticipated rapid development of autonomous maritime transport, such a state of affairs is not only outdated but also should not be accepted.

$5 \mathrm{G}$ networks will allow huge transmission rates, and provide services with low latency, high reliability and Quality of Service (QoS), and observed from users the Quality of Experience (QoE). 5G is a metamorphose of the network philosophy gives unprecedented opportunities to access services, but also 
the ease and flexibility of their implementation, without the participation of a mobile network operator.[25]

On the other hand, the development direction is set into the Software-Defined Networking (SDN), Network Function Virtualisation (NFV) and global expansion of machine-type communications in the IoT (Internet of Things).[13][15] 5G solutions will improve new groups of services dedicated to different transport applications. It allows the global extension of Intelligent Transportation Systems. So, it is also not a reason why they would not be able to influence the development of marine transport and communication systems.

The aim of this article is both the presentation of $5 \mathrm{G}$ network possibilities as well as review and discussion on the use of $5 \mathrm{G}$ technologies and concepts in maritime solutions. In section 2 , there are presented the principles of the $5 \mathrm{G}$ network, including virtualisation and network slicing. In section 3, possible types of services are discussed which are taken into account for implementation in marine applications. Section 4 presents the original network slicing model, which can be taken into account for advanced softwarisation and virtualisation within the maritime network based on $5 \mathrm{G}$ solutions, both terrestrial and satellite. The model is adjusted to different types of services planned for implementation in the future marine systems. Moreover, there are discussed the benefits form the use of network slicing in maritime applications. The last section discusses the models of the $5 \mathrm{G}$ architecture for marine systems.

\section{THE 5G NETWORK PRINCIPLES, NETWORK SLICING, AND VIRTUALISATION / Principi 5G mreže, raščlanjivanje mreže i virtualizacija}

\subsection{The principles of $5 \mathrm{G}$ network / Principi $5 G$ mreže}

The realisation of the $5 \mathrm{G}$ system needs the implementation of a large number of base stations (New Generation Node B gNB), and it should be implemented using the heterogeneous network. In the terrestrial network, it means the necessity of the use of several small-cells for communication. Additionally, in the transport V2X (Vehicle-to-Everything) communications, there can be used cooperative communication between vehicles (cars, trucks, buses, others) and road infrastructure. This concept is a chance for maritime solutions development. [2][9][13]

Significant properties of the $5 \mathrm{G}$ system should be defined, taking into account their technological evolution and the philosophy of work. Thus, the $5 \mathrm{G}$ system is a global wireless access system or the set of systems, combining mechanisms, techniques, algorithms, informatics and radio communications applications, and thus built in the radio-informatics technique. The radio-informatics is then a new terminology, absolutely justified, due to the dominant role which plays informatics in the radio communication solutions.

The principle of $5 \mathrm{G}$ is the softwarisation of the network (the concept of Software Defined Network - SDN) by using software equivalents of network nodes and virtualisation of their functions (Network Function Virtualisation - NFV).[24] Network softwarisation and virtualisation of its functions means typically parallel software implementation and realisation of complex network functions and nodes. They can be replaced by software using techniques of imitation devices.

$5 \mathrm{G}$ is an all-IP system which enables the high rate data transmission, transferred between persons, machines, vehicles and other devices, frequently without human interaction, in the essential part comprising the loT and V $2 \mathrm{X}$ communication. These techniques guarantee the revolution in safety, management, and control of traffic, and autonomous driving development. [13][15]

The $5 \mathrm{G}$ system can work with high transmission rates, high stability and reliability of connections and achieved rates, low service latency and energy consumption, for a large number of terminals supported per unit area. The essence of $5 \mathrm{G}$ is that the data should be transferred without any hindrances in quasi-real-time, and the data rate should not be a barrier to the implementation of any new services.

On the other hand, the way of system implementation is an entirely new solution because there will be possible the implementation of both physical and virtual parts of the core network, radio access network (RAN), and virtual softwarelogical different type subnetworks, called network slices. [19][26] These slices can be coordinated by Virtual Network Operators (VNO), in general, in the application network layer, configured as end-to-end applications, and dedicated for the implementation of different services. Thus, we can use the same infrastructure for different groups of services (GoS) and various applications. It is crucial for maritime and other transport solutions.

Parts of logical virtual network architecture are based on various techniques of virtualisation. It enables virtualisation of different functions, typically provided by hardware nodes. Mentioned functions can be combined into certain comprehensive functional groups implemented as software, which allows sending information between these groups. This process is called NFV. Virtual network resources and functions can be implemented in a computing cloud, and also using the software-implemented hardware and communication nodes.

The achievement of $5 \mathrm{G}$ system objectives needs the implementation of short-range gNBs, relay nodes, advanced antenna arrays based on massive-MIMO (Multiple Input Multiple Output) and utilise several access points. On the other hand, it is necessary to use cooperative transmission, especially for transport solutions (road and maritime) based on V2X. In this solution, the function of relaying can be located in User Equipment (UE), which can transmit and receive signals to or from other UEs.

To achieve substantial requirements of transmission rate and received signals, quality Ultra-Dense Networks (UDN) using small-cells should be implemented. The implementation of these cells is based on the concept of the heterogeneous network in which can be used different radio interfaces and subsystems, not necessarily $5 \mathrm{G}$. However, a significant part of the global $5 \mathrm{G}$ network will be constructed based on modern cellular systems, especially on the evolving LTE (Long Term Evolution)[15], and New Radio (NR) solutions.

Taking into account the standardisation process, we can see that the general $5 \mathrm{G}$ architecture is, from a logical point of view, the same as in 4G.[4][8] However, the main difference is located in software architectures and network functions, which include advanced solutions for softwarisation and virtualisation, never seen before in radio communications. It should be noted that final architecture of $5 \mathrm{G}$ network will integrate LTE EPC (LTE Evolved Packet Core) and so-called 5GC (5 Generation Core) solutions, these architectures will become 
a de facto unity, complement and integrate each other.

In general, there are highlighted three main parts of the standardised $5 \mathrm{G}$ architecture: NG RAN (New Generation RAN), UE, and 5GC. At the initial stage, the LTE EPC will be used as an integrated core network only. However, the overall $5 G$ system will include both the $5 \mathrm{G}$ NR parts, as well as an evolved LTE system, called, at this moment, LTE Advanced Pro. The importance of both 5 G NR and evolved LTE should be treated equally because the $5 \mathrm{G}$ NR is dedicated to small-cells while the LTE can be used in micro- and macrocells.

For maritime solutions, there is a discussion and initial work on the problem of satellite $5 \mathrm{G}$ components development. It can be used both existing solutions (Iridium, Inmarsat, Global Navigation Satellite System - GNSS), as well as new systems more adequate to $5 \mathrm{G}$ technology and advanced positioning. For the 5G/LTE based solutions, we should take into account sea-specific signal propagation conditions for systems design and modelling, as discussed in [14].

\subsection{Virtualised 5 G network slicing / Virtualizirano raščlanjivanje $5 \mathrm{G}$ mreže}

Network slicing opens the new era in communications. In general, for the $5 \mathrm{G}$ network, there are defined primary groups of services (GoS) of different requirements, including:

- Enhanced Mobile Broadband Services (eMBB) - regular services provided by today's networks: phone calls, internet, multimedia streaming, others.

- Machine-Type Communications services (mMTC) - IoT services of low data rate, but serving a massive set of devices.

- Ultra-Reliable Low Latency Communications (URRLC) services of very low latency (eventually, $<1 \mathrm{~ms}$ ) related to devices control and mission-critical services.

- Other, not strictly defined services.

Each of these groups can be used in maritime applications. [5] For instance, V2X communications or autonomous shipping are related to URLLC. Some traffic control systems can be allocated in mMTC. Video streaming, internet access can be located in eMBB, etc.

Quality characteristics and requirements for these services are entirely different. It means that we have various needs from different system characteristics. There can be mentioned e.g.: physical resources allocation for a given service, efficiency of their use, protocol implementation, meet the QoS or QoE defined for a given service, signal power requirements, SINR (Signal-to-Interference and Noise Ratio), accepted latency, spectral efficiency, BER (Bit Error Rate), BLER (Block Error Rate), and others.

It is evident that better network efficiency we can achieve when built different networks meets defined GoSs requirements. As mentioned, in $5 \mathrm{G}$, there is possible the implementation of network slices within a single, the same hardware infrastructure. So, VNOs can create unique logical networks providing services for different applications.[24] If we take into account, the GoSs listed before, then it is possible to implement different slices within the $5 \mathrm{G}$ network, what we can see in Figure 1.

The network slice can be seen as a virtual subnetwork of the real physical network, which is used to provide services within one of the available GoSs. In general, a slice is a unit of programmable network resources, made available as a network service and allowing virtual use of physical network resources (networking functions). The slice is also providing computing network functions and saving and storing information (storage functions). Network slices include all necessary and available network resources that are commonly configured. They are physical, virtual, dedicated or shared, and can be created, changed and deleted using the functions of management and orchestration. Notable is that some parts of each slice can be isolated from other slices or shared partially or entirely, especially when an application needs to use a set of services of different QoS/QoE requirements. Certain management functions, as well as resource management, can be provided by VNOs.

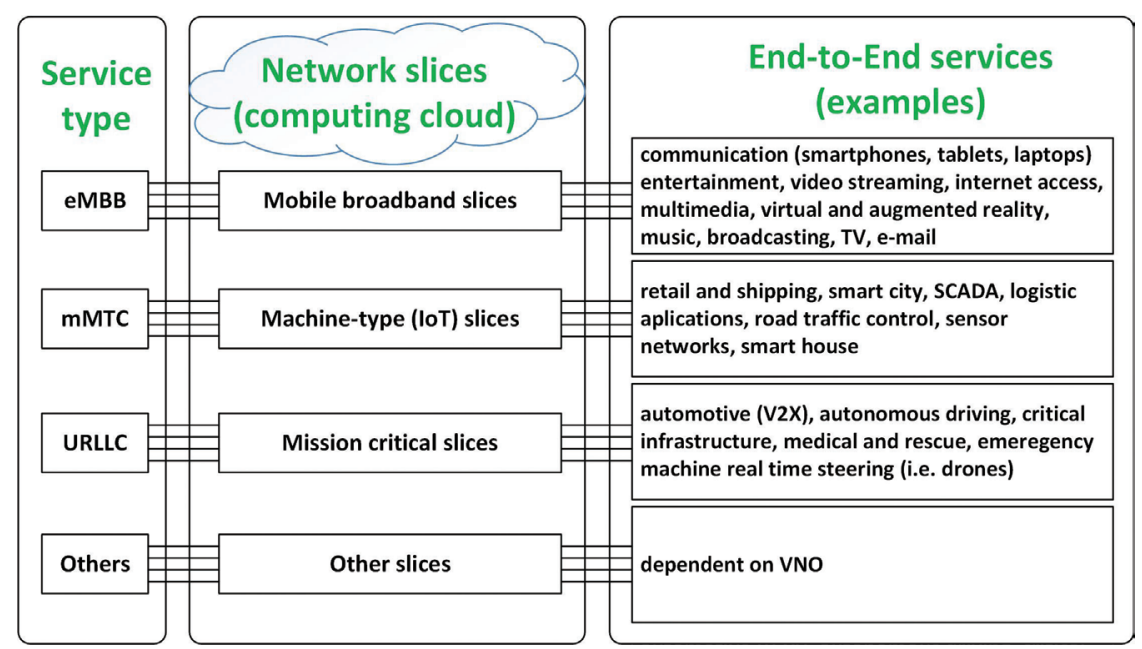

Source: own study

Figure 1 Network Slicing in $5 \mathrm{G}$

Slika 1. Raščlanjivanje u mreži $5 G$ 


\section{PROPOSALS OF MARITIME COMMUNICATION SERVICES OVER THE 5G SYSTEM / Prijedlozi usluga pomorskih komunikacija kroz 5G sustav}

The perspective of global change in the concepts of maritime communications is potentially lovely. A set of possible new services is extensive and consists of several services dedicated to a vessel service, private use by seamen, maritime safety and others. Below is presented short characteristics of possible usage of different classes of services in the future maritime applications based on 4G/5G radio communications.[1][6]

\subsection{Mobile broadband services for users at sea /} Mobilne širokopojasne usluge za korisnike na moru 3.1.1. Video streaming in the cabin or in the deck / Videoprijenos u kabini na palubi

The video streaming is an important broadband service needed in vessels. The problem for signals propagation is steel material used to the construction of vessels, which significantly attenuates radio communication signals.[6][16] That is why the communication system model for a vessel includes indirect communication using additional nodes (UEs) playing the role of relays for transmission of signals from/to a given UE, which is called cooperative transmission. In this case, it is necessary to install dedicated relay nodes or the use of dedicated UE providing the relaying service. UEs or nodes located on the deck directly (or indirectly) accessing 5G/LTE RAN using terrestrial or satellite communication.[10][11] Note, that only UEs on the deck have to be subscribed and connected to 5G/LTE network.

Anticipated requirements for these services include support of the extreme long-range of the system at sea (up to $100 \mathrm{~km}$ ), standardisation of relaying-cooperative communication procedures and protocols, standardisation of uplink and downlink direct and indirect connections and video streaming for users at sea, and service continuity between indirect and direct communication both at sea and in a vessel.

\subsubsection{System interoperability and safety operations /} Interoperabilnost sustava i mjere sigurnosti

The proposed system should meet the requirements for interoperability of the system when the access to a terrestrial RAN is not possible, and satellite communication is necessary as well as when the IOPS (Isolated E-UTRAN Operation for Public Safety) is used, including protocols, procedures, security aspects, prioritisation, etc. Requirements also include performing the network reselection when public terrestrial-coastal networks are available, and access to the local services accessible via 3GPP network on board of a vessel.[7]

3.1.3. Expanded positioning services and new use cases and 5G LAN-type services / Proširene usluge utvrđivanja pozicije $i$ novi slučajevi uporabe 5 G LAN tipa usluga

The study includes $5 \mathrm{G}$ based positioning solutions, primarily supported for indoor positioning services inside a vessel or other components and study of new use cases.[3]

\subsection{IoT communication services inside a vessel, between vessels and between UEs at sea / IoT komunikacijske usluge na brodu, među brodovima i između UEs-a na moru}

3.2.1. Communication between wearable loT devices, vessels, drones and maritime rescue coordination centre / Komunikacija između potrošnih loT naprava, brodova, dronova i pomorskih spasilačkih koordinacijskih centara

These solutions change the concept of sea safety entirely. Each worker and passenger can take UE and a boarding ticket activating dedicated devices (air jacket, smart band, another wear or devices). User devices automatically register to the Maritime Rescue Coordination Centre (MRCC) at land and transmit location information, heartbeat, and other medical information. Information can be sent between different UEs and under the seawater to MRCC.[1][6][12]

Advanced solutions can meet the requirements: wake up commands to UE, automatic and manually activated emergency requests with user information, communication with dedicated drones and vessels, supporting direct and indirect communication.

\subsubsection{Mobility management for a group of UEs / Upravljanje mobilnosti za grupu UEs}

Dedicated tracking sensors for this service can support both saving life actions, e.g. ferry passengers as well as to support logistics and keep tracking the status of them during the transportation on land and at sea. Requirements needs, e.g. mapping of UEs, vessel identity, passenger identity. For logistics, it is necessary to manage the mobility of containers.[6][18]

\subsubsection{Push to Location service among vessels / Poticaj za Uslugu lociranja među brodovima}

Push to Location service provides accident information from a vessel to all nearby vessels, operating drones, and rescue operation centres. Requirements meet high reliability, low latency, the range not less than $15 \mathrm{~km}$ and implementation aspects of the service.[6]

3.2.4. Implementation of small cells in each cabin of a vessel / Implementacija malih stanica na svaku od kabina broda

Wireless access is critical from the point of view of keep tracking cabin crews in a vessel. The steel vessels construction makes the radio signal too weakened to go through walls and be delivered to neighbouring cabins.[6] It is necessary to implement UDN with small-cells within each cabin and part of a vessel, taking into account signal propagation conditions. The transmission should be implemented both for MBB services as well as IOT safety communication.

Requirements meet mapping the location information of each cabin in a vessel (small-cell location, UE location within a cell). Moreover, the multicast and broadcast transmission of the information received from UE working as an IoT device via a small-cell to a target UE (operation centre, master of the ship, sailors, etc.) is necessary. 


\subsection{Maritime communication services between authorities and users at sea / Usluge pomorskih} komunikacija među autoritetima i korisnicima na moru It includes many services dedicated to: navigation, rescue operations, telemedicine services, and include [6][20][21][22]: vessel shore reporting, communication for search and rescue (emergency requests with the location information of the UE at sea to MRCC, notification message, maritime response message including the location information of the authority, mission-critical video communication, coast guard, health organisation for telemedical service, coastal and local warning service, supporting pilotage service, tugs service, support fishing boats, and other services: urgent alarm service with auto-identification system (AIS), Vessel Traffic Service (VTS), Navigational Assistance Service (NAS), Traffic Organisation Service (TOS), Local Port Service (LPS), Telemedical Assistance Service (TAS), Maritime Assistance Service (MAS), Nautical Chart Service (NCS), Nautical Publications Service (NPS), Ice Navigation Service (INS), Meteorological Information Service (MIS), and Real-time Hydrographic and Environmental Information Service.

\section{THE MODEL OF NETWORK SLICING FOR MARITIME APPLICATIONS / Model raščlanjivanja mreže za pomorske aplikacije}

The general model for network slicing has been proposed, which can be taken into account during the implementation of maritime services in the $5 \mathrm{G}$ network. The principle of this model is a hypothetical mapping of different services to proper GoS what makes the service implementation easier, faster and more flexible to the use in practice, and opens public $5 \mathrm{G}$ networks for maritime applications.

\subsection{The model of network slicing adapted to maritime communications / Model raščlanjivanja mreže adaptiran za pomorske komunikacije}

As mentioned, for maritime communications within the 5G network (and other 3GPP networks) there is proposed a broad set of services of different importance. Maritime communication imposes a necessity to adopt required marine services to this model. The model for slicing referring to services defined in section 3 is presented in Figure 2.

\subsubsection{Slicing for enhanced mobile broadband services for users at sea / Raščlanjivanje poboljšanih mobilnih širokopojasnih usluga za korisnike na moru}

The two first sets in Figure 2, consist of enhanced Mobile Broadband Services for Users at Sea, which can be located to a GoS of eMBB of a classical model. However, we can see that in terrestrial applications, the characteristics of services are not wholly the same as in maritime applications. First, we have different propagation conditions dependent on the environment.[14] Thus, during the process of service quality parameters definition, we must take into account the requirements for at least four variants of transmission:

- LTE transmission between the UE located at the deck of a vessel and coast base stations gNB (5G) or eNB (LTE base stations).
- $5 G$ satellite transmission between a UE at a vessel and satellite, and between a satellite and terrestrial gNB for satellite communication.

$5 \mathrm{G}$ communication on the vessel using several gNBs and relaying UEs, and in this, both direct and indirect communication, including other 3GPP or non-3GPP wireless systems.

- $5 G$ communications links for relaying in configurations vessel-to-vessel, vessel-to-drone, based on different transmission technologies, etc.

For each communication scenario, we should define different network slices due to various environmental requirements, and taking into account services defined in 3 . The satellite transmission needs an additional definition of slices and services parameters and requirements, and it is marked in Figure 2 as satellite sMBB. Satellite transmission is of higher transmission latency and can be of less transmission rate compared to standard eMBB service.

\subsubsection{Slicing for loT machine-type communication services / Raščlanjivanje loT strojnih komunikacijskih usluga}

The third set consists of IoT services inside a vessel, between vessels and between UEs at sea, which is, in general, massive machine-type communications. These services were specified for terrestrial 5G. However, it can be noted that in maritime systems in this set we have many services which are essential for sea safety. It means that requirements for maritime services should be defined differently compared to terrestrial system services, and include sea-specific situations and requirements, as presented in section 3 .

In the case of communication between wearable IoT devices, vessels, drones and MRCC are the entire set of services dedicated to saving of life and property at sea. Moreover, these services should meet the IMO (International Maritime Organisation) and other authorities' requirements.

Mobility management for a group of UEs in a vessel should be coordinated in a different way for seamen, passengers, and vessel types while the support of logistics is an entirely different type of service. The same problems we can see in Push to Location service group among vessels.

In turn, the implementation of small-cells in each cabin of a vessel can be dedicated for both standard eMBB transmissions as well as for keeping tracking cabin crews in a vessel and safety and rescue applications in a different way. Of course, we must configure different slices for various services.

For communication over satellite components, we should define additional slices due to limited scenarios for IoT communication by satellite, marked as satellite sMTC.

4.1.3. Slicing for maritime communication services between authorities and users at sea / Rašćlanjivanje kod usluga pomorskih komunikacija među autoritetima i korisnicima na moru

A maritime communication service is a large set of different services, and their allocation is difficult. In this case, there is necessary to define a set of indicators and make decisions about the allocation to URLLC mission-critical services set or 


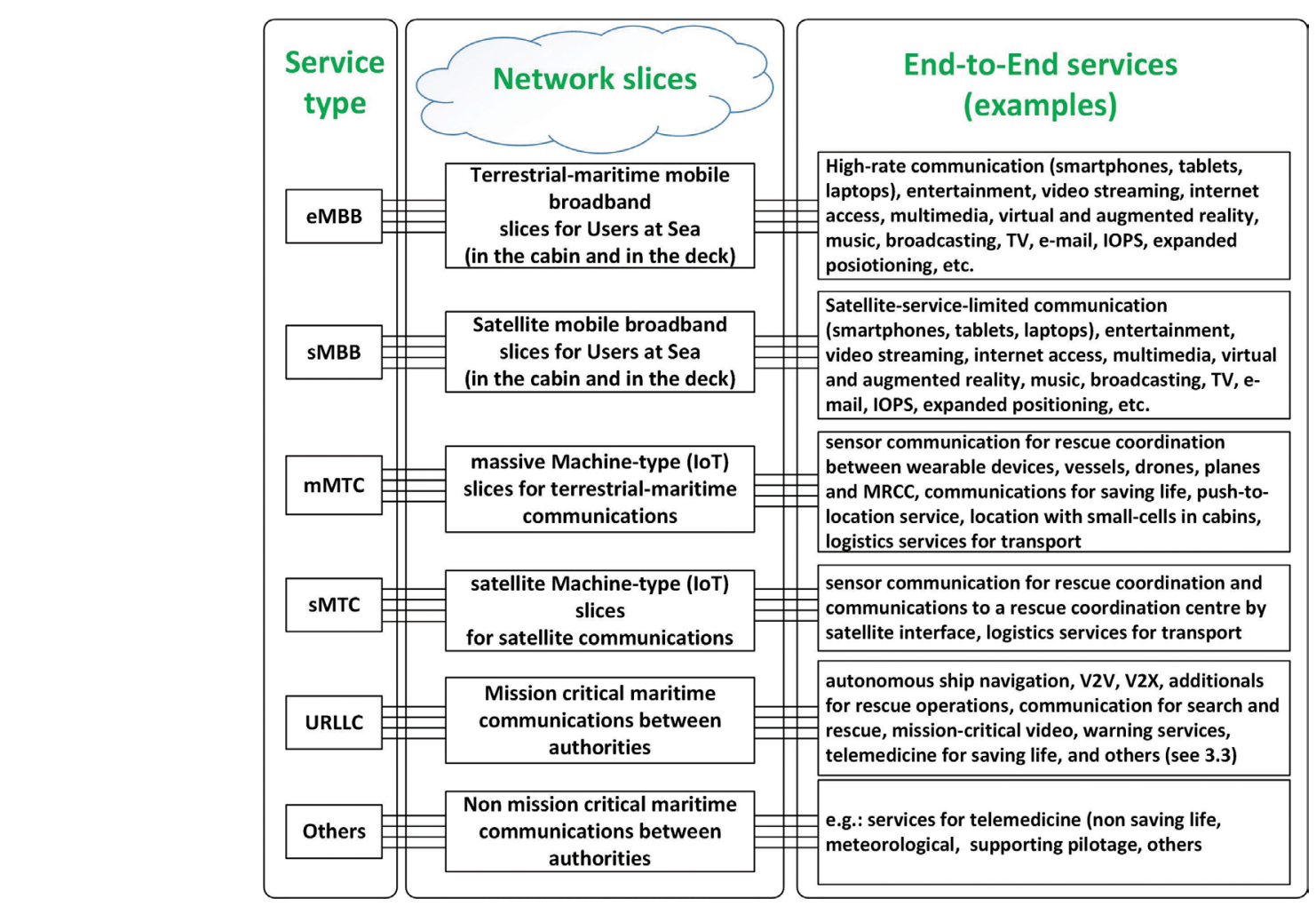

Source: own study

Figure 2 The $5 \mathrm{G}$ network slicing model proposal for maritime solutions Slika 2. Predloženi $5 G$ model raščlanjivanja mreže za pomorska rješenja

other types. It needs additional work what is not a subject of this paper. However, we see that using the concept of network slicing we can configure several slices in a different way for various services and very important is that it is flexible and can be changed and expanded during system exploitation. Thus, the software-virtualised network evolution is relatively possible and straightforward. Moreover, it is an excellent chance (and challenge) for faster development of different maritime solutions using global civilian networks of enormous potential.

\subsection{Consequences of network slicing for maritime communications / Posljedice raščlanjivanja mreže za pomorske komunikacije}

As seen before, the $5 \mathrm{G}$ network gives great potential for evolving maritime applications in a relatively short time because of the high flexibility of software-defined and virtualised parts of network implementation. To understand the essence of problems discussed in this paper, we analyse a generalised model for standard communications system design, universal both for civilian as well as for professional systems, as we can see in Figure 3.

Of course, the presented procedures scientifically are not complete and need standardisation. However, in Figure 3, we can see the main difference between previous systems and 5G. All previous types of radio communication systems were designed in the way that the first step is the defining services types and requirements, and next defining system requirements because we must know what for we can design the system first. In the case
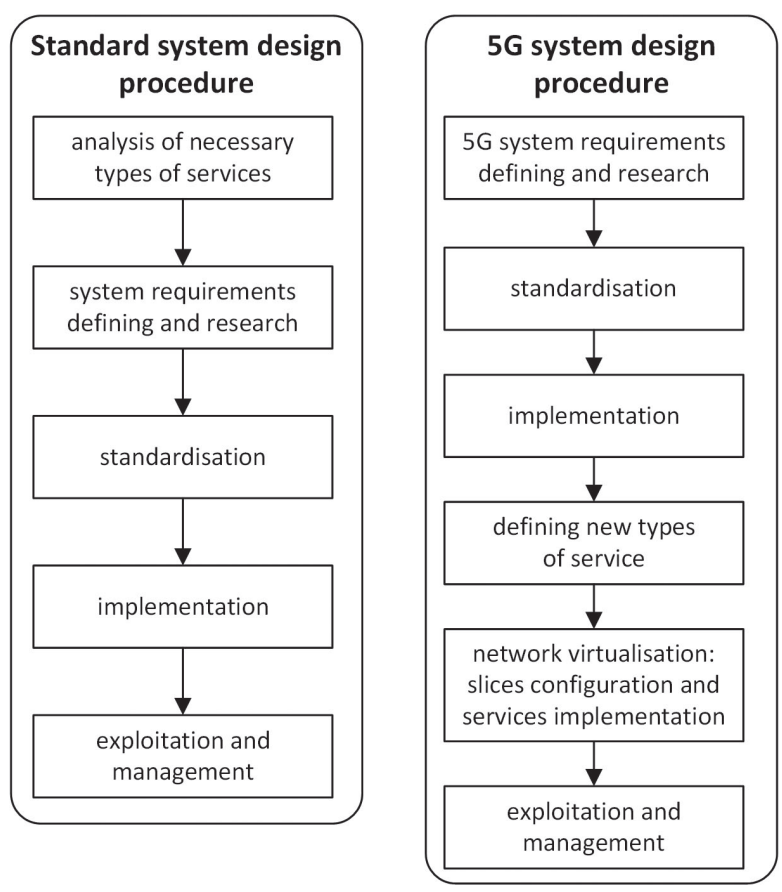

Source: own study

Figure 3 The generalised procedure of system design for standard communication systems and $5 \mathrm{G}$

Slika 3. Generalizirana procedura sustava dizajna za sustave standardnih komunikacija i $5 G$ 
of $5 G$, this model is modified because we first defined system requirements (to a certain extent), build system infrastructure and implement software-defined parts, and next, we give the system at our disposal. Moreover, this is a moment when the system can be used in different ways by VNOs. Now we can use available system infrastructure and implement services within reserved slices for which we can define requirements. Thus, we take types of service, define slice requirements, types of slices, etc., and configure proper virtual subnetwork for a new application, especially maritime one. In conclusion, we can say that we use the same network infrastructure and resources for the implementation of different virtual subnetworks for various applications.

The essence is that VNO can configure a network slice as an end-to-end type application. So, it is flexible, but we should say: it is the target and challenge. However, using network slicing, we can reduce network implementation, construction, and exploitation costs, optimise resource management in a network, optimise terrestrial and maritime transport networks, and also reduce global energy consumption.

However, primary importance, from maritime transport systems development, is an excellent possibility of the optimisation services quality and resource consumption. It is possible due to the isolated configuration of different GoSs. There is possible the optimisation of entire GoS, taking into account service requirements within a single group. We can control connections within a group, while there is not necessarily independent control of several separated connections and services. The result is greater service efficiency, higher quality, and less latency. It can be critical for maritime safety connections.

If the global $5 G$ infrastructure is introduced, then the design of modern, professional systems for maritime communication will be much simpler, and the costs will be significantly reduced.

\section{THE 5G NETWORK ARCHITECTURES FOR MARITIME SOLUTIONS / 5G arhitektura mreže za pomorska rješenja}

The architecture of the $5 \mathrm{G}$ network, in general, is similar to the $4 \mathrm{G}$ architecture. As mentioned, it consists of NG RAN, UE, and 5GC.[23] The LTE 4G and Beyond 4G solutions will be a significant, integrated part of the overall $5 \mathrm{G}$ network. At the initial stage, the $5 G C$ will not be implemented while the Evolved Packet Core (EPC) of LTE will be the core network for $5 \mathrm{G}$ solutions.

\subsection{Maritime 5G network based on terrestrial 5G/LTE communications / Pomorska 5 G mreža temeljena na terestičkim 5G/LTE komunikacijama}

The first model is dedicated to the communications over terrestrial-public 5G/LTE network. However, the use of it is possible only when a signal of satisfying quality is available on the vessel deck (see Figure 4). In this case, the communication to the $5 \mathrm{G}$ network is realised by UEs, which are adapted to $5 \mathrm{G}$ communication, directly to terrestrial-coast gNB and indirectly using cooperative links over other UEs in a vessel. Thus, it needs additional standardisation of relaying transmission over
5 G UEs. The UEs communicating with terrestrial gNB, typically, should be located on the deck due to a tremendous signal loss inside cabins. These UEs have to allow relay communications from UEs located in cabins.

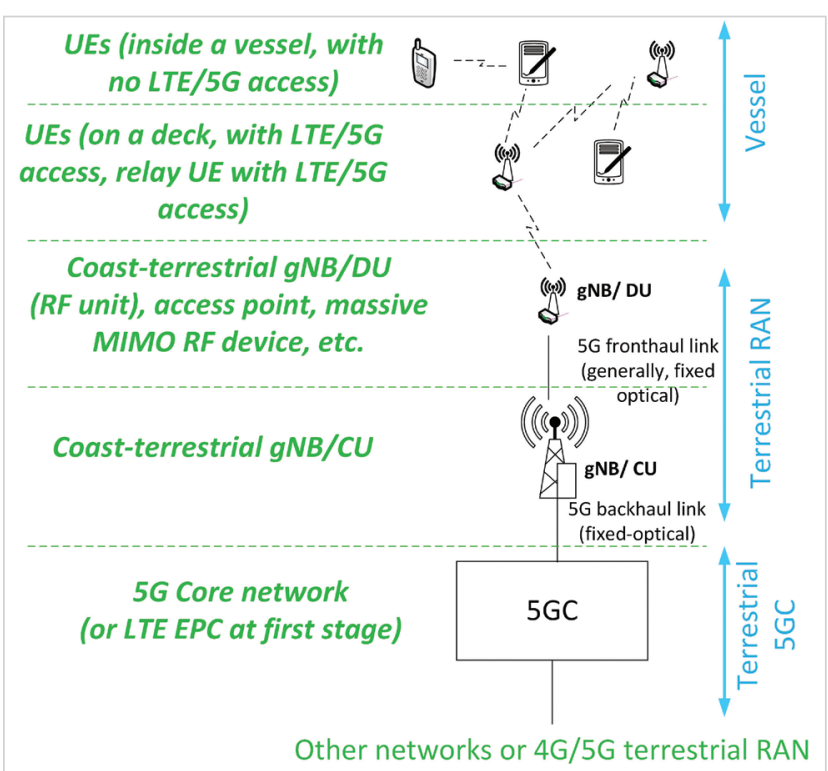

Source: Own study

Figure 4 The general architecture of maritime communication system based on terrestrial access

Slika 4. Općenita arhitektura sustava pomorskih komunikacija temeljena na terestičkom pristupu

In typical situations, direct communication between UEs and coast-terrestrial base stations will be provided to gNB/ DU (Distributed Unit). The gNB/DU is instead the only RF unit (Radio Resource Unit - RRU), which is a part of gNB located in desirable locations and managed by $\mathrm{gNB} / \mathrm{CU}$ (Central Unit). It is very likely that the communication to gNB/DU, in general, concerns the transmission of useful user data only while the transmission to $\mathrm{gNB} / \mathrm{CU}$ concerns the control data, as well as the control and user data, as it was proposed for terrestrial $5 \mathrm{G}$ systems. Thus, the terrestrial RAN includes both gNB/DUs as well as gNB/CUs.[2] The $5 G C$ core network will be a part of the terrestrial $5 \mathrm{G}$ network.

\subsection{Maritime 5G network based on satellite access / 5G pomorska mreža temeljena na satelitskome pristupu}

The satellite $5 G$ solutions are necessary when the coastterrestrial network is not available. It is not sure how it will be implemented due to a very early phase of a standardisation. The model of UEs communication in a vessel is the same as in the previous case, but UEs for satellite communications must be equipped with satellite modems.

The complexity of $5 \mathrm{G}$ satellite network architecture significantly grows because it is necessary to implement a satellite part of RAN what we can see in Figure 5. Predominately at the moment, it is assumed that the satellite part of 5G RAN will be the distributed unit gNB/DU of the base station, while the coast-terrestrial part will be the $\mathrm{gNB} / \mathrm{CU}$. In this case, there is possible the management of many satellite gNB/DUs by 
a coastal gNB/CU. However, both the gNB/CU and gNB/DU must transmit both the control and data information, what is the difference compared to the previous model. The other difference is that the fronthaul links between $\mathrm{gNB} / \mathrm{CU}$ and gNB/DU are satellite links while in the terrestrial model they were fixed-optical.

The process of standardisation of the $5 \mathrm{G}$ satellite is instead at the initial phase, but without the satellite component, efficient use of $5 G$ achievements will not be possible in maritime communications. The high chance for it results from the concepts for terrestrial 5G New Radio which can work at high frequencies which correspond to satellite communication, too. Thus the similarity of radio interface construction is possible, and terrestrial solutions can be partially adapted to the satellite.

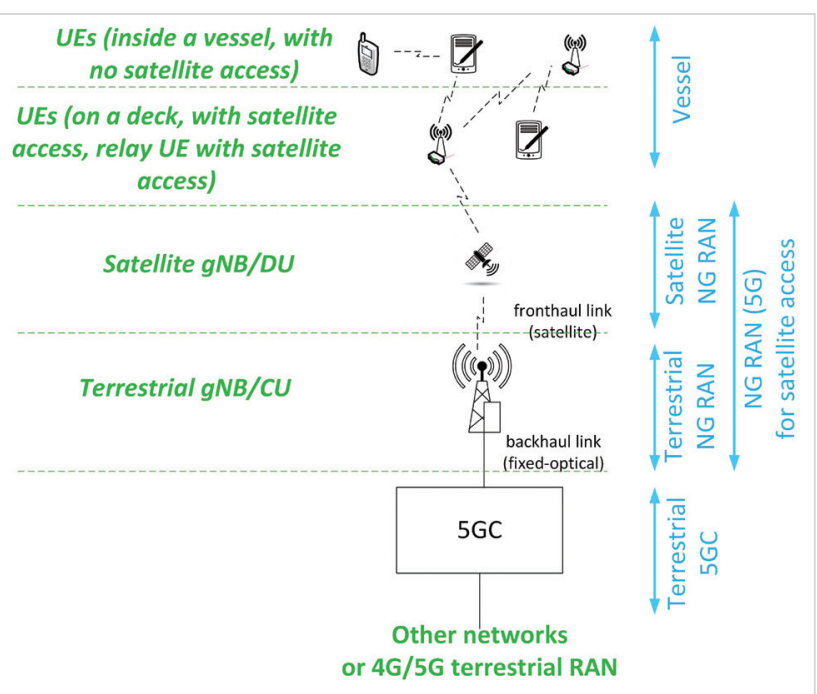

Source: Own study

Figure 5 The general architecture of maritime communication system based on satellite access

Slika 5. Opća arhitektura sustava pomorske komunikacije temeljena na satelitskome pristupu

\section{CONCLUSION / Zaključak}

The development of satellite $5 \mathrm{G}$ components for maritime communications is rather not sure. However, it is evident that without it, it will not be possible to use $5 \mathrm{G}$ services and achievements in maritime communications, and they will not be up-to-date. If the autonomous shipping is a practice and global loT communication is to be truly global, then the $5 \mathrm{G}$ satellite component must be embodied. Only the hybrid communication over both terrestrial and satellite $5 \mathrm{G}$ network guarantees the metamorphosis of maritime communications what is necessary.

As mentioned in this paper, the network slicing implementation and use of its resources is a revolution and challenge. However, from this point of view, we should talk about radio-informatics network rather than a radiocommunication one. The aim is that the implementation of specific parts of a global network will be possible due to specific requirements, especially for maritime communication and 5G NR.[5] The model of slicing presented in this paper is an incentive to take into account this aspect when defining the assumptions and standardising the $5 \mathrm{G}$ system for maritime communication. This model must be carefully elaborated from maritime regulations and service requirements, which is not the topic of this paper. However, it provides an excellent opportunity for the development of maritime applications adequate to the state of view and the improvement of global maritime safety.

\section{LITERATURA / References}

[1] 3GPP TR 22.819 V16.2.0.: Feasibility Study on Maritime Communication Services over 3GPP system; Stage 1, 2018, Release 16, $3^{\text {rd }}$ Generation Partnership Project, TSG Services and System Aspects, 5G Technical Report.

[2] 3GPP TR 22.822 V16.0.0.: Study on using Satellite Access in 5G, Stage 1, 2018, Release 16, $3^{\text {rd }}$ Generation Partnership Project, TSG Services and System Aspects, 5G Technical Report.

[3] 3GPP TR 22.872 V16.1.0.: Study on positioning use cases, Stage 1, 2018, Release 16, $3^{\text {rd }}$ Generation Partnership Project, TSG Services and System Aspects, 5G Technical Report.

[4] 3GPP TR 38.801 V14.0.0: Study on new radio access technology: Radio access architecture and interfaces, 2017, Release 14, $3^{\text {rd }}$ Generation Partnership Project, TSG Radio Access Network, $5 \mathrm{G}$ Technical Report.

[5] 3GPP TR 38.811 V15.0.0.: Study on New Radio (NR) to support non-terrestrial network, 2018, Release 15, $3^{\text {rd }}$ Generation Partnership Project, TSG Radio Access Network, $5 \mathrm{G}$ Technical Report.

[6] 3GPP TS 22.119 V16.0.0.: Maritime Communication Services over 3GPP system, Stage 1, 2018, Release 16, $3^{\text {rd }}$ Generation Partnership Project, TSG Services and System Aspects, $5 \mathrm{G}$ Technical Specification.

[7] 3GPP TS 22.346 V15.0.0.: Isolated Evolved Universal Terrestrial Radio Access Network [1E-UTRAN) operation for public safety, Stage 1, 2018, Release 15, $3^{\text {rd }}$ Generation Partnership Project, TSG Services and System Aspects, LTE Advanced Pro Technical Specification.

[8] 3GPP TS 23.501 V16.0.2.: System Architecture for the 5G System, Stage 2, 2019, Release 16, $3^{\text {rd }}$ Generation Partnership Project. TSG Services and System Aspects. 5G Technical Specification.

[9] Alonistioti, N.: Blue Growth loT. Smart Maritime Initiative - 5G + IoMT, 2017, Presentation from ETSI Workshop "Future evolution of marine communication", Sophia Antipolis, France.

[10] Bogens, K.: GMDSS modernisation and e-navigation: Spectrum needs, 2017 Presentation of BR Terrestrial Services Department, ITU, ETSI Workshop "Future evolution of marine communication", Sophia Antipolis, France.

[11] EMEA Satellite Operators Association (ESOA): Satellite Communication Services: An integral part of the 5G Ecosystem, 2017, Presentation from ETSI Workshop "Future evolution of marine communication", Sophia Antipolis, France.

[12] Gajewska, M.: Application of BAN Network to Increase Security in Transport Systems, 2017, Book chapter: Mikulski J. (eds) Smart Solutions in Today's Transport, Communications in Computer and Information Science, Springer, Cham, Vol 715, pp. 155-166, (ISBN 978-3-319-66251-0), https://doi. org/10.1007/978-3-319-66251-0_13

[13] Gajewska, M.: Novel proposal for V2X systems and WBAN cooperation to improve road safety, 2017, Proceedings of the 15th International Conference on ITS Telecommunications (ITST), Warsaw, Poland, May 29-31, pp. 1-5, (ISBN: 978-1-5090-5275-2), https://doi.org/10.1109/itst.2017.7972232

[14] Gajewski, S.: Design of OFDM-based radio communication systems for coast-to-sea and coast-to-air propagation environments, 2016, Polish Maritime Research, Gdansk, Poland, No. 1/2016, Vol. 23, pp. 12-19, (ISSN: 1233-2585), https://doi.org/10.1515/pomr-2016-0002

[15] Gajewski S.: Perspectives of Transport Systems Development in the Light of Radio Communication Systems Evolution Towards 5G, 2017, Book chapter: Mikulski J. (eds) Smart Solutions in Today's Transport, Communications in Computer and Information Science, Springer, Cham, Vol 715, pp. 203-215, (ISBN: 978-3-319-66251-0), https://doi.org/10.1007/978-3-319-66251-0_17

[16] Hyounhee, K.: Maritime Communication Services over 3GPP systems, 2017, Presentation of SyncTechno Inc. from ETSI Workshop "Future evolution of marine communication", Sophia Antipolis, France.

[17] Kitindi, E., J., Fu, S., Jia, Y., Kabir, A., Wang, Y.: Wireless Network Virtualization With SDN and C -RAN for 5 G Networks: Requirements Opportunities, and Challenges, 2017, IEEE Access, Vol. 5, pp. 19099-19115, (ISSN: 2169-3536), https://doi.org/10.1109/access.2017.2744672

[18] Katulski, R., Sadowski, J., Stefański, J., Ambroziak, S., Miszewska, B.: Selforganizing wireless monitoring system for cargo containers, 2009, Polish Maritime Research, Gdansk, Poland, No. 3 (61), Vol. 16, pp. 45-50, 2009, (ISSN: 1233-2585), https://doi.org/10.2478/v10012-008-0033-5 
[19] Khatibi, S., Caeiro, L., Ferreira, L., S., Correia, L., M., Nikaein, N.: Modelling and implementation of virtual radio resources management for $5 \mathrm{G}$ Cloud RAN 2017, EURASIP Journal on Wireless Communications and Networking, No. 128, pp. 1-16, (ISSN: 1687-1499), (ISSN: 2471-2833),https://doi.org/10.1186/ s13638-017-0908-1

[20] NCSR 1-28: Report to the Maritime Safety Committee, International Maritime Organisation (IMO). Sub-Committee on Navigation, Communications and Search and Rescue, 2014.

[21] NCSR 4/29: Report to the Maritime Safety Committee, International Maritime Organisation (IMO), Sub-Committee on Navigation, Communications and Search and Rescue, 2017.

[22] NCSR/WP.4: Report of the Navigation Working Group, International Maritime Organisation (IMO). Sub-Committee on Navigation, Communications and Search and Rescue, 2017.
[23] Parkville, S., Dalman, E., Furuskar, A., Frenne, M.: NR: The New 5G Radio Access Technology, 2017, IEEE Communication Standards Magazine, Vol. 1 Issue 4: 24-30, pp. 24-30, https://doi.org/10.1109/mcomstd.2017.1700042

[24] Richart, M., Baliosian, J., Serrat, J., Gorricho, J., L.: Resource Slicing in Virtual Wireless Networks: A Survey, 2016, IEEE Transactions on Network and Service Management, Vol. 13, No. 3, pp. 462-476, (ISSN: 1932-4537), https:// doi.org/10.1109/tnsm.2016.2597295

[25] Rost, P., Berberana, I., Maeder, A., Paul, H., Suryaprakash, V., Valenti, M., Wübben, D., Dekorsy, A., Fettweis, G.: Benefits and Challenges of Virtualization in 5G Radio Access Networks, 2015, IEEE Communications Magazine, Vol. 53 , Issue 12, pp. 75-82. https://doi.org/10.1109/mcom.2015.7355588

[26] Sallent, O., Pérez-Romero, J., Ferrús, R., Agusti, R.: On Radio Access Network Slicing from a Radio Resource Management Perspective, 2017, IEEE Wireless Communications, Vol. 24, Issue 5, pp. 166-174, (ISSN: 1558-0687 ), https:// doi.org/10.1109/mwc.2017.1600220wc 